\title{
Network Design and Tracking for Sewage Disposal and Management Using Geographic Information System and Remote Sensing For Mubi, Adamawa State, Nigeria
}

\author{
${ }^{1}$ Shuaibu M. A., ${ }^{1}$ Sulaiman I. M. and ${ }^{2}$ Aliyu, R.M. \\ ${ }^{I}$ Surveying and Geoinformatics Programme Abubakar Tafawa Balewa University, Bauchi, \\ ${ }^{2}$ Dept. of Surveying and Geoinformatics, Modibbo Adama University of Technology, Yola.
}

\begin{abstract}
This research employed both GIS and Remote Sensing for the sewage network design and tracking for Mubi to aid in the disposal management of sewage in the area. Sewage is the mix of water and whatever that is liquid wastes from domestic and industries that are flushed and propelled by gravity through pipes into the cesspit. The topography of the area for smooth flow of sewage using remote sensing data and ArcGIS software package was accessed. Also, direction of flow for sewage was identified. Both contour and vector maps as a results of the analysis for the study area were produced. Proposed sewage network based on the results was designed that consisted of three categories of sewers; primary, secondary and tertiary. The primary collect sewage from houses, commercial areas, etc., to the secondary and then to tertiary and to the final collection centers planned to be laid by the access roads, minor and major roads respectively. All the collection centers will finally emptied the sewage in to River Yedzeram outside the metropolis as in Fig.10, 11 and 12.
\end{abstract}

Keywords: GIS, Remote Sensing, Sewage disposal, Design, Tracking

\section{INTRODUCTION}

Sewage also known as waste water is the water-carried waste both in solution or suspension that is intended to be disposed from a community (Wikipedia, 2012). Sewage consists of mixture such as water and whatever that is liquid wastes from domestic and industries flushed into the sewers (Sludge News, 2012).

A sewage network is a system of sewer pipes (sewers) which collects sewage and takes it for treatment or disposal. Where a main sewage network has not been provided, sewage may be collected from homes by pipes or vehicles into septic tanks or cesspits, where it may be treated and disposed. Septic tanks that are properly functioning require emptying for every two to five years depending on the load of the system (Wikipedia, 2012). A sewage system's conduits are typically made of clay, plastic or concrete, and they're usually built so that gravity will propel waste through them. There are different types of sewers for servicing sewage from a variety of sources: Individual buildings deposit their sewage into collecting sewers that carry waste to a central location for treatment; Sanitary sewers carry only domestic sewage or waste from commercial and residential buildings; Storm sewers carry runoff from melted snow and rain; Combined sewers carry both domestic sewage and runoff water; etc. The combined sewers are not ideal because overflow from heavy rains can cause untreated sewage to be discharged from a treatment plant (Science Channel, 2011).

Sewage collected in a network of sewers will include some rain and storm water which has been washed off roads and driveways, because many of sewers are combined, so they carry both sewage and surface water. However, new developments tend to separate out the surface water so that this is discharged to soak ways or watercourses rather than flowing to treatment works (Wessex Water, 2011).

Sewage and wastewater are also disposed of into rivers, streams and the sea in many parts of the world. Doing so can lead to serious pollution of the receiving water. This is common in third world countries and may still occur in some developing countries, where septic tank systems are too expensive (Wikipedia, 2012) such as Mubi in Nigeria. Sewage and wastewater affect human's health because they contain bacteria (e.g. typhoid fever, salmonella, and cholera), fungi, parasites, and viruses that can cause intestinal, lung, and other infections which may cause diarrhea, fever, cramps, and sometimes vomiting, headache, weakness, or loss of appetite (Delaware, 2011).

Because the wastes in sewage often contain toxic materials and disease-causing organisms, the safe disposal of sewage is essential to any community's well-being and is one of the most important municipal services. Most sewer systems in the United States treat sewage at a treatment plant where they destroy diseasecausing organisms and remove toxic substances. About 99 percent of the wastewater that enters a treatment plant comes out as treated water. After treatment, the sewage is usually released into nearby waterways or the soil (Science Channel, 2011). Sewage Treatment Plant is a facility designed to receive the waste from domestic, commercial and industrial sources and to remove materials that damage water quality and compromise public 
health and safety when discharged into water receiving systems (Northnmbrianwater, 2011). This happened usually when current methods for solving spatial problems are not properly applied.

With the current advances in computerized information systems, remote sensing and GIS techniques are the ideal tool that can help in the planning, design, implementation and managing sewage network.

\subsection{STATEMENT OF THE PROBLEM}

The generation of sewage or liquid waste, like any other kind of waste, is an inevitable consequence of human existence (Chup and Nwakalor, 2005). However, it is the management of the sewage that has become a problem, because of the inability of man to cope with the numerous wastes he generates in an attempt to enhance his living conditions.

In Mubi, sewage management problems have become very rampant in all locations. The area is the second largest town in Adamawa state and one of the commercial centers in Nigeria, but has no sewage management system. This may not be unconnected with the increasing rate of urbanization, coupled with inability to keep development in pace with increasing population in Mubi metropolis. The designing of this sewage network and its tracking as a panacea tool to the problem of sewage management for Mubi metropolis is a welcome development. Therefore, the research attempted the use of GIS and satellite images for the achievement of the study objectives.

\subsection{AIM AND OBJECTIVES}

The aim of this research is to apply remote sensing and geographic information system for sewage network design and tracking to aid in its disposal and management for Mubi metropolis. This was achieved through the following objectives:

(i) To assess the topography of the area for smooth flow of sewage using remote sensing data and ArcGIS software.

(ii) To design and develop sewage network system that will be easily use for sewage management in the metropolis.

(iii) To apply the system in (ii) above for wastewater collection and treatment services for the metropolis.

(iv) To analyze the system when applied in terms of granting the metropolis' source of water free from contamination.

(v) To highlight the importance of the system in relation to human and industrial effluents to be disposed of without danger to human health or unacceptable damage to the natural environment.

\section{II. study area}

The study area is geographically located between Latitudes $10^{\circ} 30^{\prime}$ and $10^{\circ} 05^{\prime} \mathrm{N}$ and Longitudes $13^{\circ} 10^{\prime}$ and $13^{\circ} 30^{\prime} \mathrm{E}$ North of the Greenwich Meridian (Figure 1). It lies on the west bank of the Yedseram River, a stream that flows north into Lake Chad, and is situated on the western flanks of the Mandara Mountains which form its both drainage system and relief. The area is bounded internationally by Cameroon and within the state by Michika to the east, Hong to the west and Maiha to the south. Also, it occupies an area of $192,307 \mathrm{~km}$ and has a population of 260,009 people (National Population Census, 2006).

Probably founded in the late 18th century by the Fulani people, Mubi remained under the jurisdiction of the sultanate of Mandara until conquered by Modibbo Adama. By the 1820s the peoples of Mubi and the surrounding area were incorporated into Adama's Fulani kingdom of Fombina, later called Adamawa; in the 1890s they were subjected to slave raids by Adamawa's emir Zubairu. The town was taken by German forces in 1903 and served as a frontier post and administrative centre of German Kamerun until its capture by the British in 1914. Mubi and its surrounding region were placed in the British Cameroons by a League of Nations mandate in 1922. In 1961 it became part of Nigeria (Sardauna province) (Mubi, 2012). Mubi is a town in Adamawa state, Nigeria. The major tribes are Fulanis from Digil as well as the Fali People from Vimtim. Names like Nuhu Auwalu Wakili are very common in the state. The Nuhu Wakili's family is the ruling family in the town. It is home to the state university, Adamawa State University, Mubi (ADSU, 2012).

Mubi exhibits both dry and wet tropical climate type. The dry season begins in November and ends in March, while the rainy season runs from April to October each year. Rainfall annually is about $900 \mathrm{~mm}$ with highest frequencies in July and August. Temperature ranges from warm to hot throughout the year but experience cool period between November and February with gradual increase in January to March. The relative humidity of the area is low but begins to rise from April to August maximally (Adebayo, 2004).

The vegetation zone of the study area is within the sudan savanna belt of Nigeria and is referred to as the cambretaceous woodland savanna (Areola, 1983). The natural vegetation is altered by human activities for farming and building from the naturally about $70 \%$ of grasses and weeds with few scattered woody plant. 


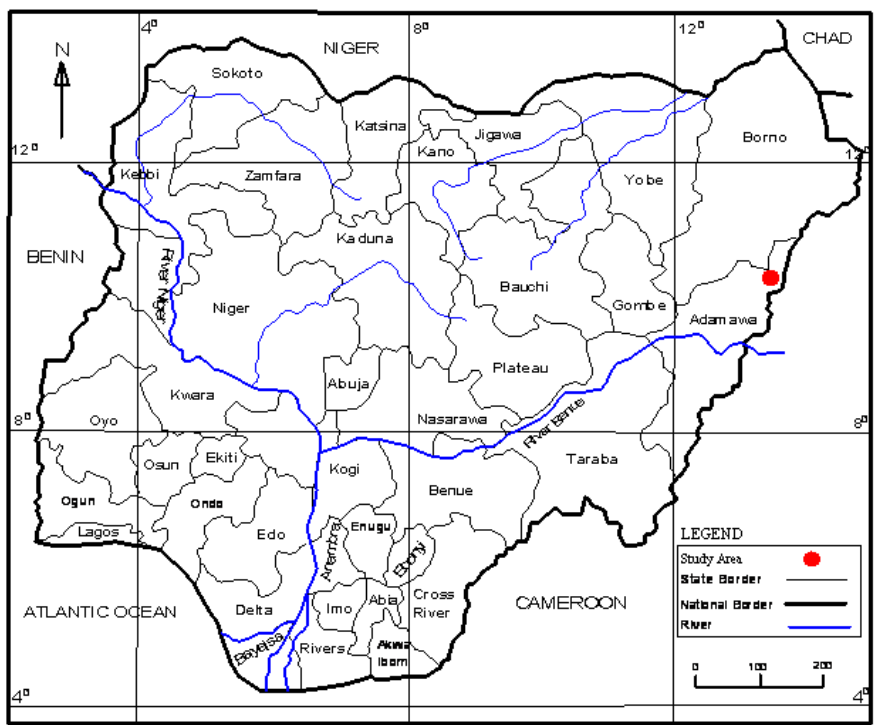

Figure 1: Map of Nigeria showing the study Area. Source: (ADSU, 2012)

\section{Methodology}

In this chapter, a comprehensive description of the data acquired, the equipment used, the software applied and various methods adopted in this research work will be stated.

\subsection{Data}

The data requirement of this research consisted of the following:

- Quick Bird image of Mubi town, obtained from geography department, Adamawa state University, Mubi.

- Coordinates of four prominent points within the study area obtained with the use of Global Positioning System (GPS). The points and their coordinates are Police Station Roundabout $(310504 \mathrm{mE}, 1135173 \mathrm{mN})$, Maiha Junction along Ahmadu Bello Way (308684E, 1135661mN), G.R.A. Roundabout (311033mE, $1136819 \mathrm{mN})$ and Kaban Junction along Maiha Road (308802mE, 1133532mN).

- $\mathrm{X}, \mathrm{Y}, \mathrm{Z}$ Coordinates (spot height) of some points within the study area were obtained with the help of Global Positioning System (GPS).

\subsection{Equipment and Software}

\subsubsection{Equipment}

The following facilities were available for this study:

- Acer (Aspire 3680) laptop computer (Celeron M).

- HP Photosmart (C5500 Series) printer, scanner and photocopier.

- Garmin 12 channel GPS receiver (hand held).

\subsubsection{Software}

The software consisted of:

- Microsoft Word

- CorelDraw 11

- ILWIS 3.1 Academic

- $\quad$ ARCVIEW 3.2 a

- $\quad$ Surfer 7

\subsection{Conversion of Image into TIF}

The satellite image obtained and used for the study was opened in CorelDraw software environment, converted into Tagged Image Format (TIF) then exported to ILWIS software for further processing.

\subsection{Georeferencing and Resampling}

The exported image was then imported into ILWIS software via GeoGateway. Georeferencing was achieved by using coordinates (Northings and Eastings) of the four points as tie points identified on the image (Figure 2). After the georeferencing, the image was resampled and exported to ARCVIEW software for digitizing and compilation. 


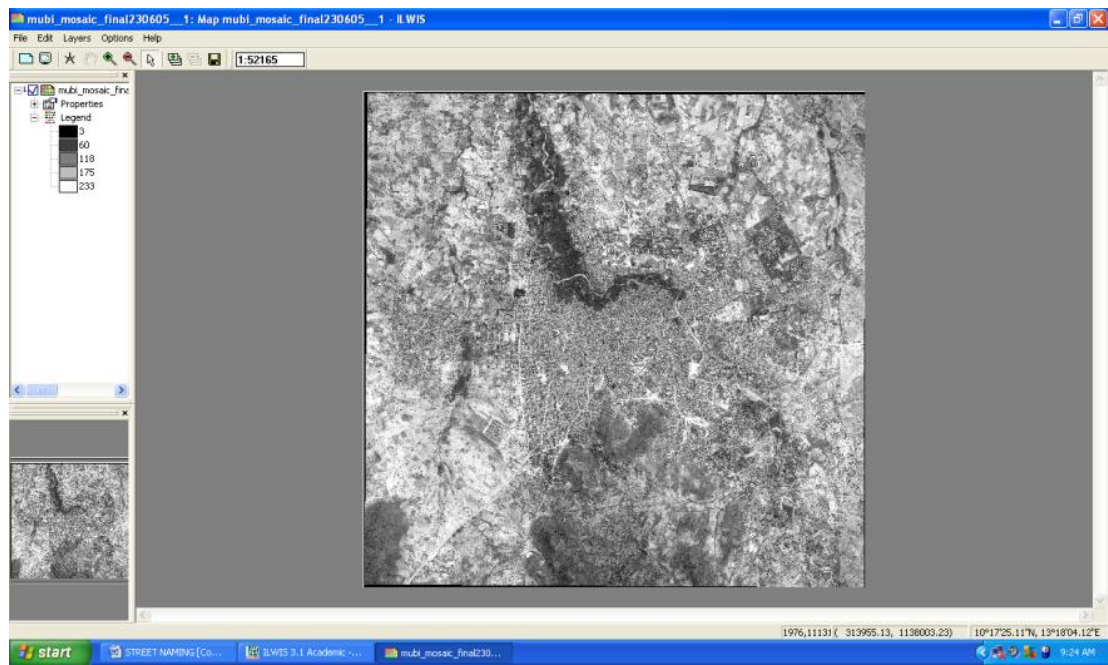

Figure 2: Georeferenced and resampled image of Mubi metropolis.

\subsection{Digitizing the features}

The features in the study area (Mubi metropolis) were identified on the image and digitized using ARCVIEW software. Each feature within the study area was digitized as independent thematic layer (Fig. 3, 4, 5 and 6).

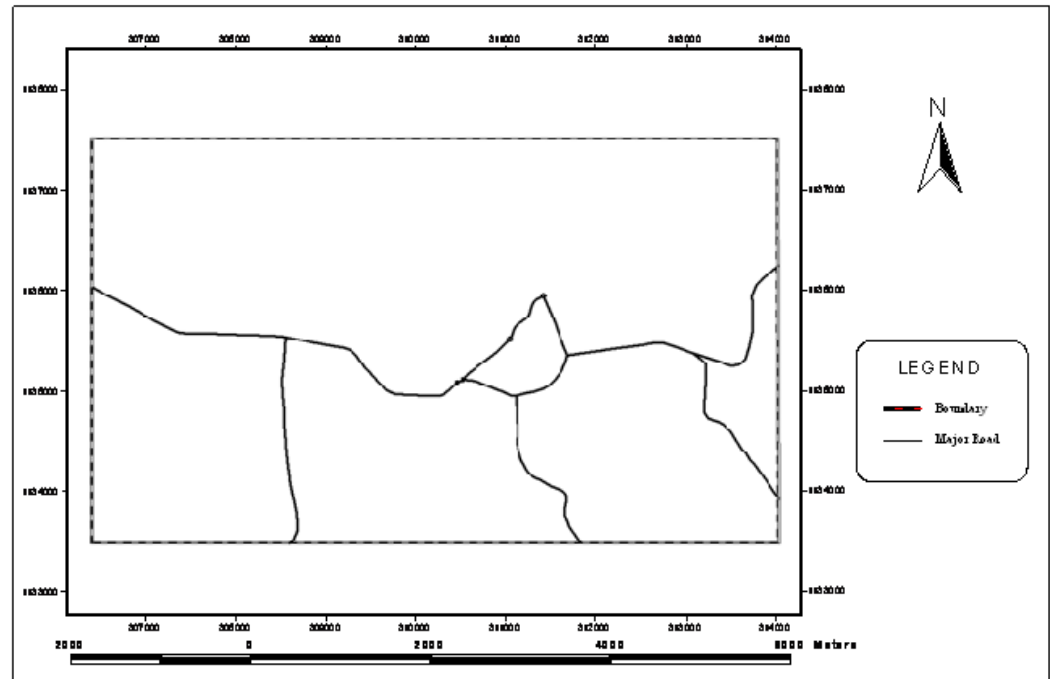

Figure 3: Major roads of Mubi metropolis.

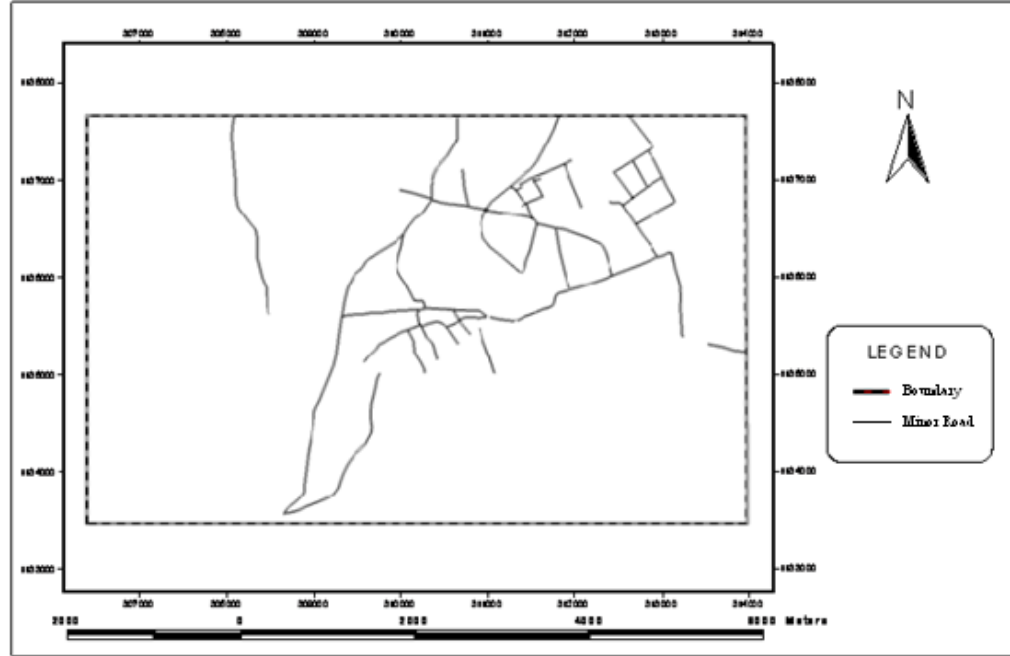

Figure 4: Minor roads of Mubi metropolis. 


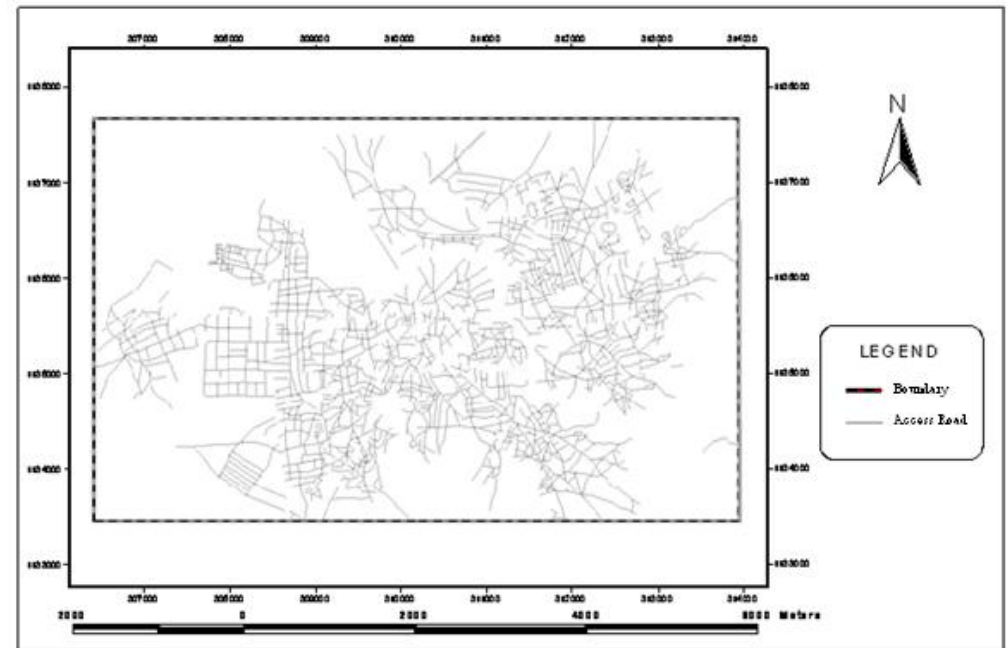

Figure 5: Access roads of Mubi metropolis.

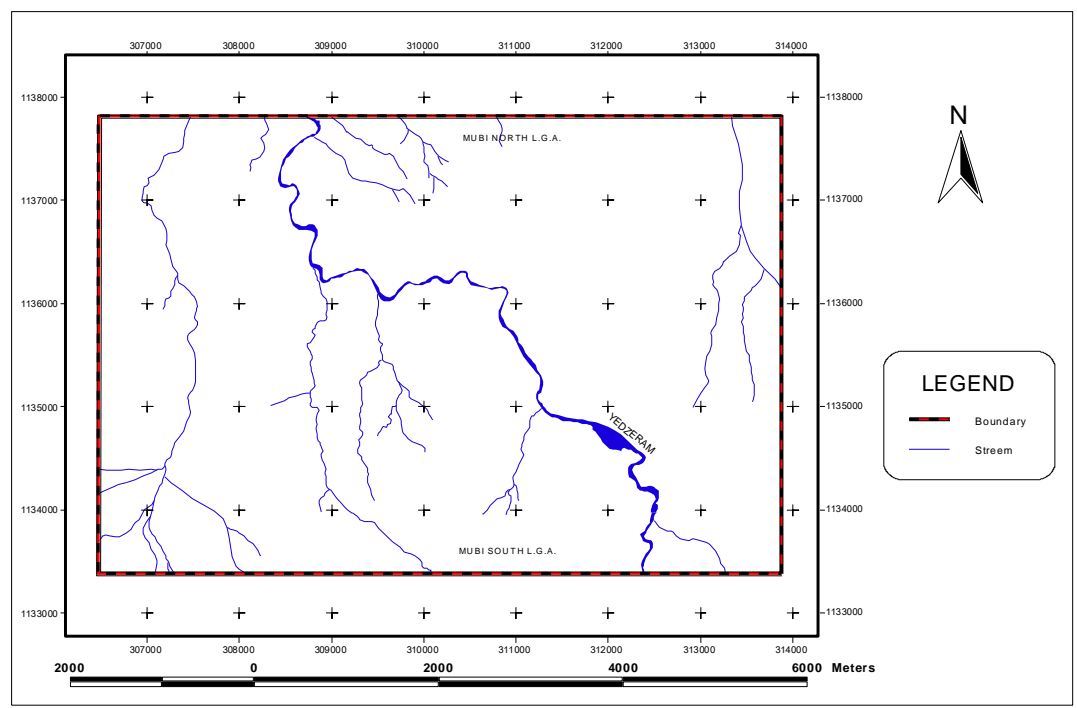

Figure 6: Water bodies of Mubi metropolis.

\subsection{Generation of contour and vector maps}

The $\mathrm{X}, \mathrm{Y}, \mathrm{Z}$ coordinates of some points within the study area were used with the aid of Surfer software to generate the contour and vector maps of the area (Figures 7 and 8).

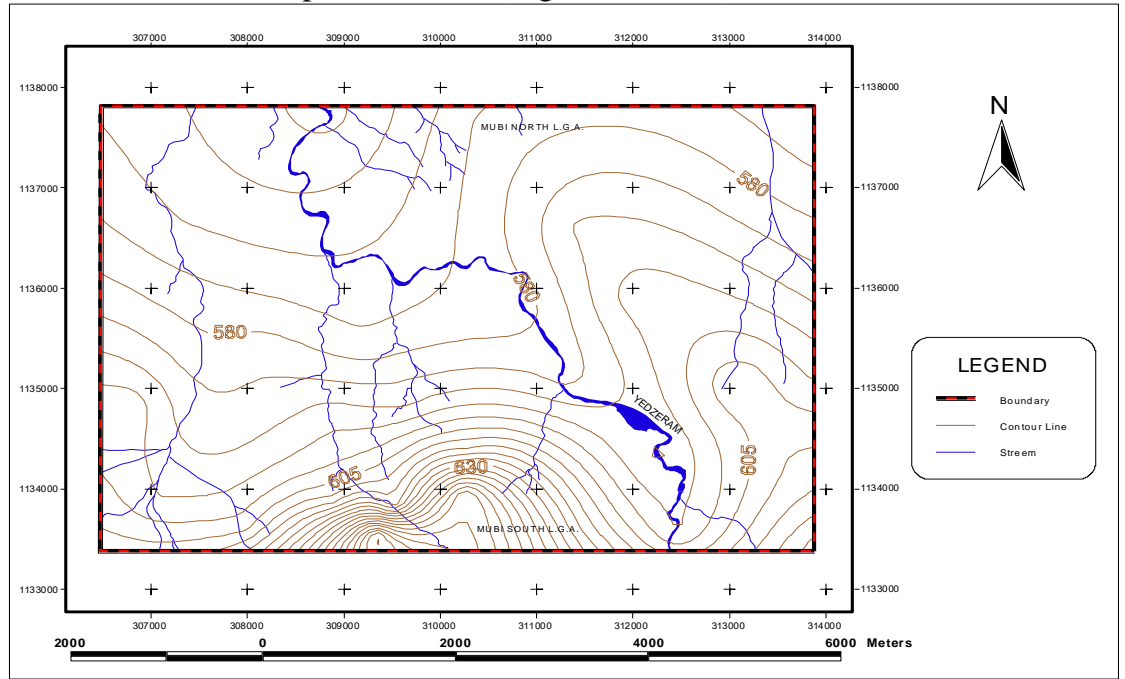

Figure 7: Contour map of Mubi metropolis. 


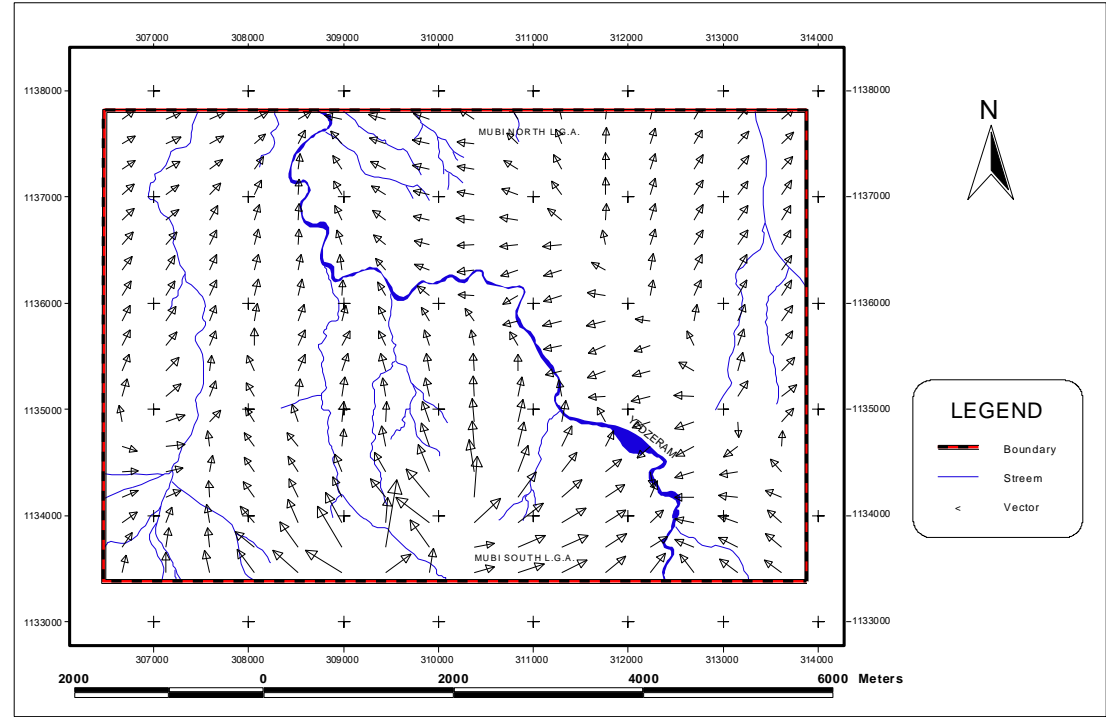

Figure 8: Vector map of Mubi metropolis.

\subsection{Composite map of the study area}

The composite map of the study area was compiled by superimposing the major roads, minor roads, access roads, water bodies, and contour and vector maps on one another (Figure 9).

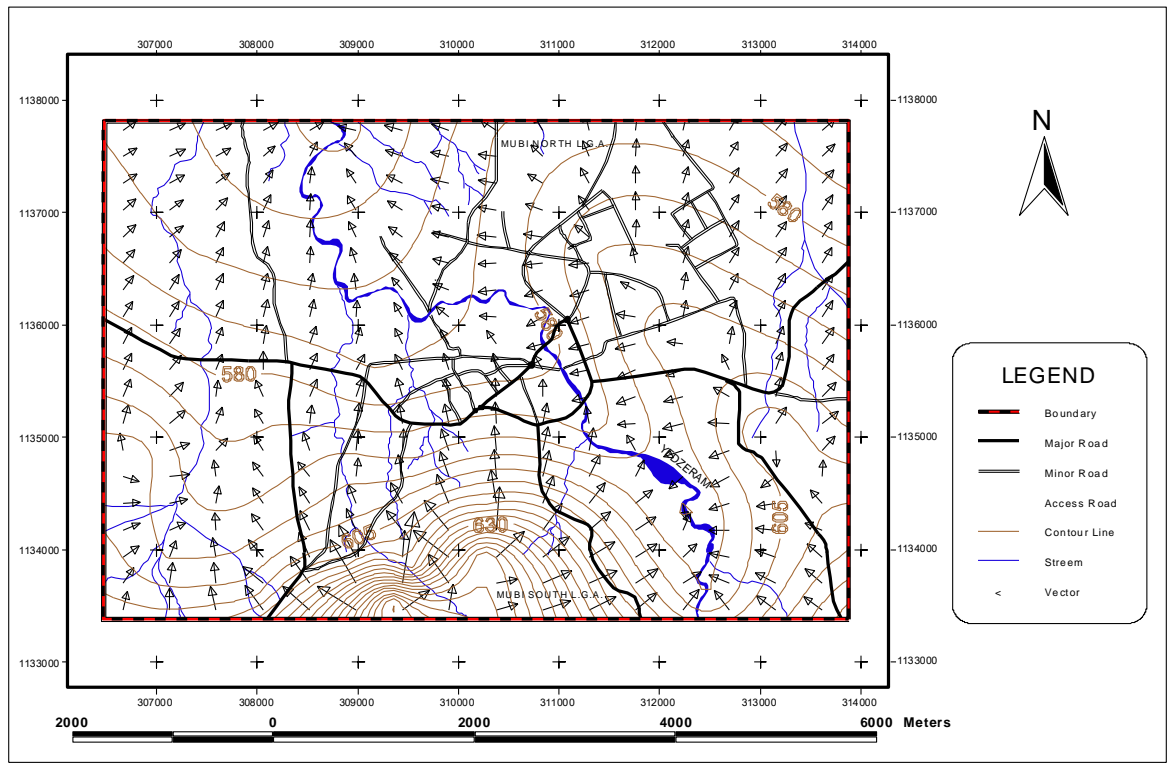

Figure 9: Composite map of the study area.

\section{Results And Discussion}

The assessment of the topography in the study area and direction for smooth flow of sewage were accomplished through the use of remote sensing data and GIS techniques with contour and vector maps as results. The proposed sewage network which consists of three categories of sewers, namely; primary, secondary and tertiary sewers was designed. The primary sewers which will collect sewage from houses, commercial areas, etc. were laid by the access roads, the secondary sewers which will collect sewage from the primary sewers were laid by the minor and major roads while the tertiary sewers which will collect sewage from the secondary sewers to collection centers were laid by River Yedzeram and outside the metropolis (Figures 10, 11 and 12). Hence, sewage will be safely transported to the desired locations and can be treated thereby causing no harm to both source of water and human life. Also, the environment will be free from disease usually associated with poor sewage system. 


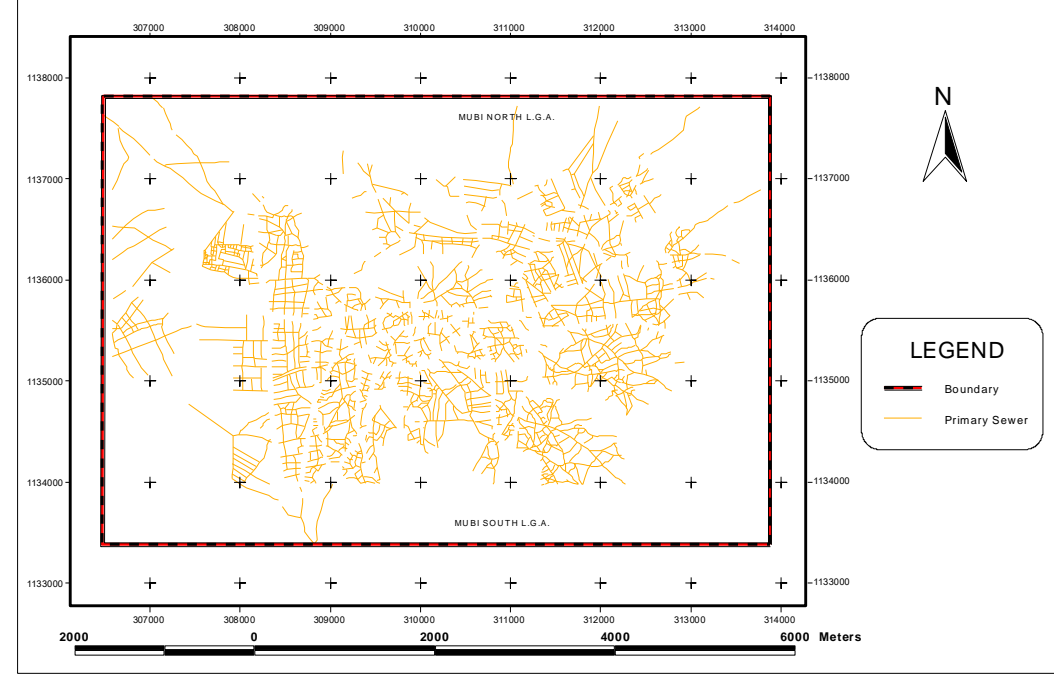

Figure 10: Proposed primary sewer.

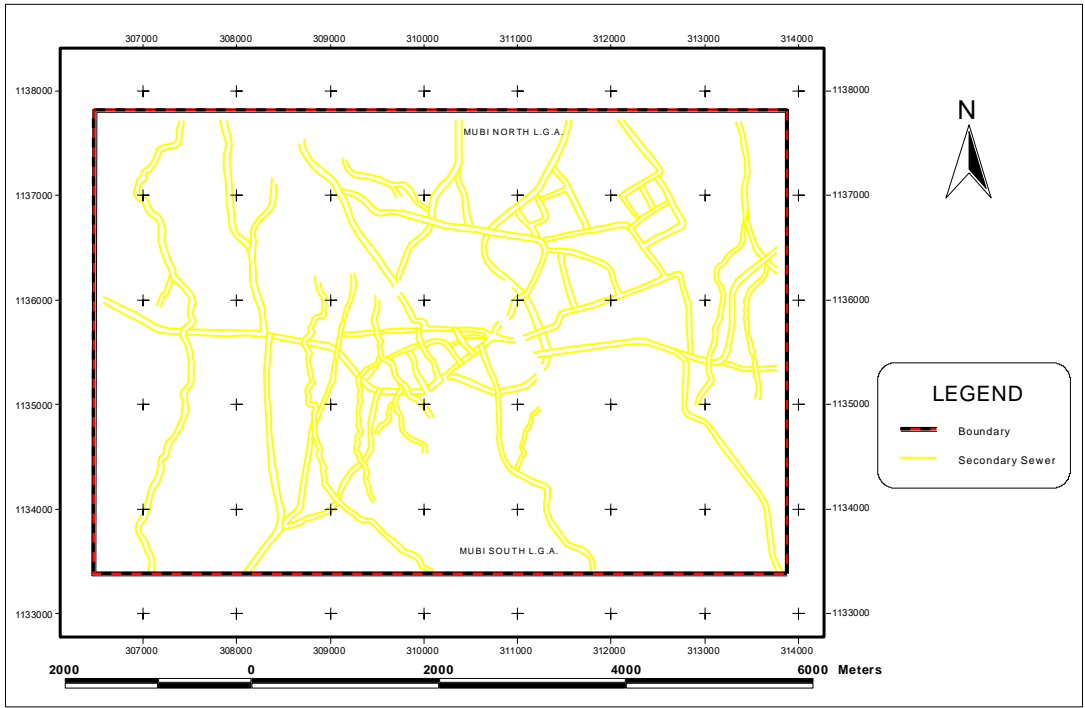

Figure 11: Proposed secondary sewer.

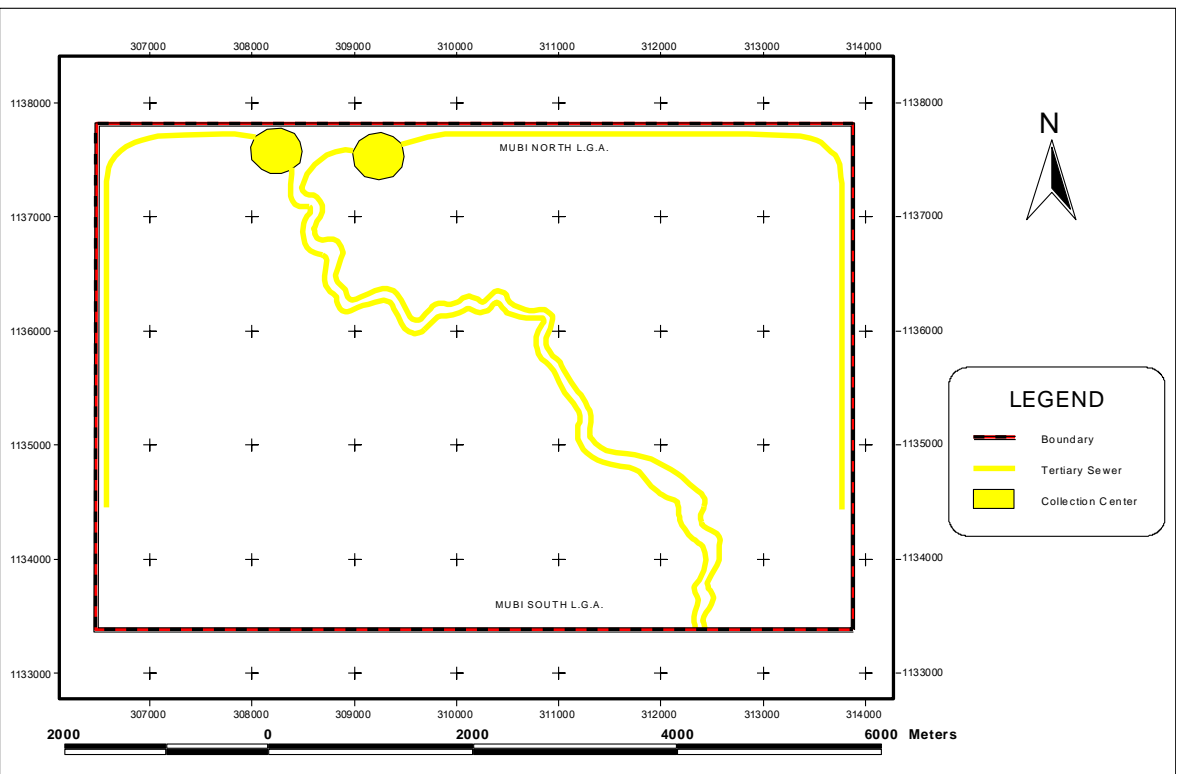

Figure 12: Proposed tertiary sewer. 
The sewage network map, produced in different layers, was compiled by superimposing the layers on one another to form a composite map (Figure 13).

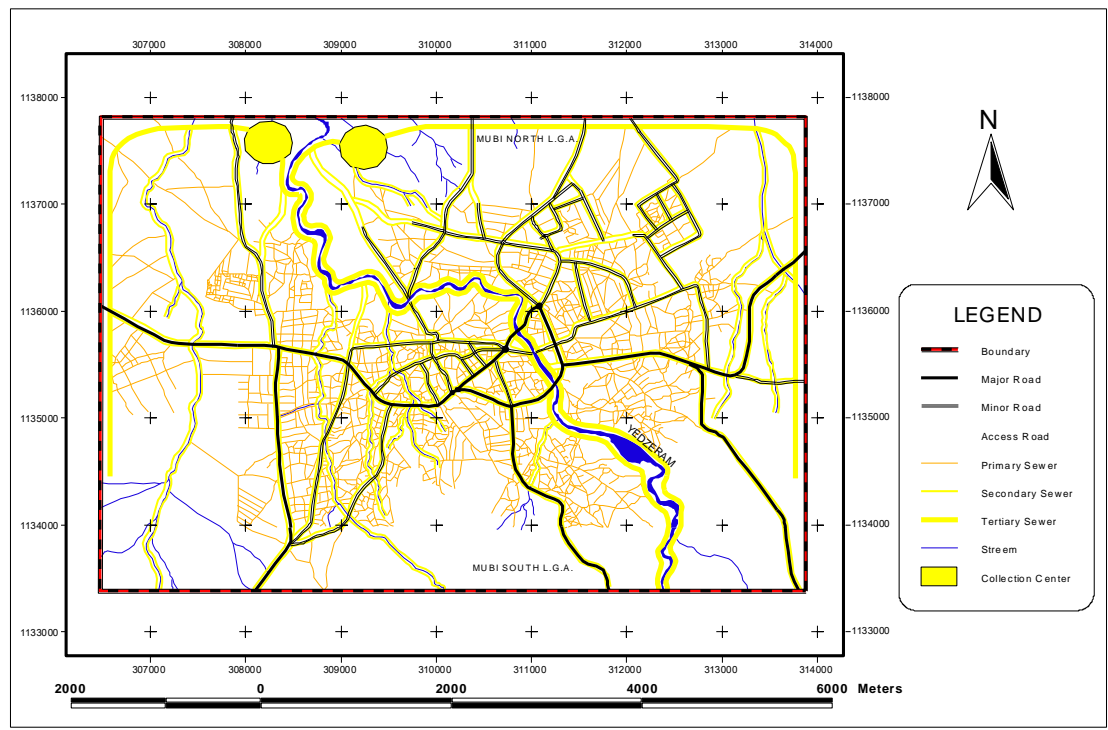

Figure 13: Sewage network map of Mubi metropolis.

\section{Conclusion And Recommendations}

The aim of this research is the design and tracking of sewage network for Mubi metropolis, through the application of remote sensing and geographic information system that has been accomplished. Sewage networks are complex infrastructure systems that have significant impact on the economic, environmental and social aspects of all modern societies. Therefore, sustainable management of these critical assets posed a wide range of challenges.

It can be seen, in this study that remotely sensed data and geographic information system can provide a reliable base for sewage network design, especially when high resolution satellite imagery is used. It is therefore recommended that:

Researchers should embrace the integration of satellite remote sensing, global positioning system and geographic information system in sewage network design and tracking.

High resolution satellite imageries should be made available at relatively low - cost to researchers to assist in the various fields of research for better results.

Appropriate authorities should adopt more proactive and optimized approaches to manage the sewage networks and plan for their short and long term renewal in a more sustainable way.

\section{Reference}

[1]. Adebayo, A. A. (2004). Mubi region, a geographic synthesis. Yola: Paraclete Poblishers. 17-37.

[2]. ADSU (2012). History of Adamawa State University. Retrieved on 21st June, 2012 fromhttp://en.wikipedia.org/wiki/Adamawa State University.

[3]. Areola, O. O. (1983). A geography of Nigerian development. Ibadan: Heinemann

[4]. Delaware Health and Social Services (2011). Sewage, http://dhss.delaware.gov/dph/files/sewage.fag.pdf. Retrieved 19/10/2012.

[5]. Encyclopedia Britannica (2012). Mubi, http://www.britannica.com/EBchecked/topic/395790/mubi. Retrieved 21/10/2012.

[6]. Mubi (2012). History of Mubi, Nigeria. Retreived on 21st June, 2012 from http://en.wikipedia.org/wiki/Mubi.

[7]. Northumbrianwater (2011). What is Sewage Treatment Plant? http://moef.nic.in/modules/recent-initiatives/NRCD/stp.htm. Retrieved 20/10/2012.

[8]. Nwakalor, B. K. (2005). Problems of sewage management in the federal capital city of Nigeria. The Zaria Geographers, Vol. 16(1). PP. $46-53$.

Science Channel (2011). What is Sewage System? http://curiosity.discovery.com/question/what-is-a-sewage-system. Retrieved 23/10/2012.

Sludge News (2012). About Sewage Sludge: What is Sewage Sludge? Wessex Water (2011). What is Sewage? http://education.melbournewater.com.au/ content/sewage_and_recycling/what-is-sewage.asp. Retrieved 18/10/2012.

[11]. Wikipedia (2012). Sewage, http://en.wikipedia.org/wiki/sewage. Retrieved 18/10/2012.

[12]. Wikipedia (2011). History of Adamawa State University, http://en.wikipedia.org/wiki/adamawa_state_university. Retrieved 21/10/2012. 